\title{
Talent identification in Hungary: From identification to investigation
}

\author{
Szilvia Péter-Szarka* \\ University of Debrecen, European Talent Centre, Budapest, Hungary
}

\begin{abstract}
This article provides an outline of talent identification practices and challenges in Hungary. First, it gives a summary of gifted education in the country; then the general challenges of talent identification are introduced: difficulties of defining talent, talent as potential, environmental factors, the role of perseverance and motivation, and individual variety. Later, recent Hungarian identification practices are shown, followed by a summary and a conclusion about how our identification practice should be developed into an investigation of individual characetristics. We propose stronger focus on the use of cognitive profile tests, investigation of interest-based characteristics, the use of observation and dynamic assessment methods, teacher nomination and emphasizing the need for effort. The focus from identification toward investigation exploring individual needs and characteristics to provide the most appropriate pathway for development in the $21^{\text {st }}$ century seems to be a more effective way of talent support than mere selection.
\end{abstract}

Keywords: talented, identification, Hungary, investigation, environmental factors

\section{Identificiranje talentiranih na Madžarskem: od identificiranja do raziskovanja}

\author{
Szilvia Péter-Szarka \\ University of Debrecen, European Talent Centre, Budimpešta, Madžarska
}

Povzetek: Prispevek predstavlja prepoznavanje talentov na Madžarskem ter nekatera še neodgovorjena vprašanja s tega področja. Najprej je podan kratek povzetek o obravnavi talentiranih na Madžarskem, nato pa so izpostavljeni nekateri aktualni problemi identifikacije talentiranih: težave pri opredeljevanju talenta, talent kot potencial, dejavniki okolja, vloga vztrajnosti in motivacije ter pomen individualnih razlik. V nadaljevanju prispevka je predstavljena obstoječa praksa identificiranja talentiranih, vključno s sklepi o nadaljnjem razvoju te prakse v smeri raziskovanja individualnih značilnosti ter $\mathrm{z}$ večjim poudarkom na uporabi testov kognitivnega profiliranja, ugotavljanja interesov, uporabe opazovanja in dinamičnih ocenjevalnih metod, upoštevanja mnenj učiteljev in poudarjanja potrebe po vlaganju napora. Zdi se, da je premik od identifikacije $\mathrm{k}$ raziskovanju oziroma ugotavljanje individualnih potreb in značilnosti posameznikov za zagotavljanje nadaljnjega razvoja $\mathrm{v}$ primerjavi zgolj s selekcijo bolj učinkovit način za podpiranje talentiranih v 21. stoletju.

Ključne besede: talentirani, identifikacija, Madžarska, raziskovanje, okoljski dejavniki

\footnotetext{
${ }^{*}$ Naslov/Address: Szilvia Péter-Szarka, PhD, University of Debrecen, European Talent Centre, Budapest, Hungary, e-mail: pszszilvia@gmail.com
}

Članek je licenciran pod pogoji Creative Commons Attribution 4.0 International licence. (CC-BY licenca).

The article is licensed under a Creative Commons Attribution 4.0 International License (CC-BY license). 
This paper about talent identification in Hungary was originally presented at a conference for teachers and school psychologists in Slovenia, which is why a short outline about Hungarian gifted education is given in order to establish the national context of identification practices. Then some general challenges and critical points of talent identification will be addressed, followed by actual identification practices in Hungary. Finally, some conclusions are drawn by showing a direction forward into new perspectives in talent investigation and by giving a more appropriate answer to $21^{\text {st }}$ century challenges.

\section{Gifted education in Hungary}

First, recent tendencies and achievements of Hungarian talent support will be presented on the basis of the summary of Csilla Fuszek (2014), the director of the European Talent Centre, Budapest.

The first milestone of recent developments in talent support was the formation of the Hungarian Talent Support Society in 1989 by 84 professionals (psychologists, lawyers, economists, bankers and entrepreneurs). The society was formed to provide an extensive social basis for bringing professional expertise and political will to support talents. The political transitions of the following years have brought major developments in the legislative environment as well. Act LXXIX of 1993 on public education declared that "children and students shall have the right to receive education and teaching in conformity with their abilities and interests, to pursue further studies in accordance with their abilities and to receive primary art education in order to discover and develop their artistic talents" (Act of Public Education, 1993, 10§). The Act codified the still existing primary-level art school system, which provides regular art courses financed mostly by normative budget contributions.

Decree No. 111/1997 of the Government on the teacher qualification requirements was also exemplary in Europe, as it was the first decree declaring that talent support should be included in the mandatory training material of teacher training. In 1999, the "Talent and its development" special educational programme was launched. This programme is currently accessible at five facilities: at the University of Debrecen, the Eötvös Loránd University, the Western Hungarian University, Szent István University and Eszterházy Károly College, with the last offering an MA programme for talent support specialist teachers.

In the $1990 \mathrm{~s}$, a positive turn took place in the legislative environment, and public and civil society initiatives in talent support also increased rapidly. The National Youth Scientific and Innovation Contest can be mentioned, as well as the Association of Researcher Students in 1996, which offers research opportunities for secondary school students at the best Hungarian research sites, with the assistance of a mentor network comprising outstanding scientists. The Academic Competition of Secondary School Students (OKTV) and the National Conference of Scientific Students' Associations give an opportunity for the best university and high-school students to present their scientific results. The Arany János Talent Support Programme was announced by the Ministry of Education in 2000, involving more than ten thousand children, and designed to enhance the chances of disadvantaged children living in small settlements to continue their education and to promote social mobility.

Although there have been several substantial public and civil society initiatives in the last two decades, they mostly functioned on their own, without close cooperation. To facilitate cooperation between these organisations, talent support activities were brought under an umbrella organisation in 2006. The National Talent Support Council started its work with six member organisations, mainly non-governmental organizations (NGOs), and currently it has 44 members and has more than 100 partner organisations and their number continues to increase. Shortly after it was founded however, the council felt the need to have a legal status to pursue its operative activities, and hence the Hungarian Association of Talent Support Organisations (MATEHETSZ) was formed from of the members of the Talent Support Council and registered in October 2006.

By 2008, the members of the council managed to jointly compile the so-called Genius Integrated Talent Support Programme, serving as the professional basis for the national talent strategy planned for 20 years. Based on this programme, talent support became a national issue. The National Talent Programme (NTP) prepared on the basis of Genius Integrated Talent Support Programme was already ready for being submitted to Parliament, so a 20-year strategy passed in Parliament in December 2008.

A new situation arose with MATEHETSZ being the beneficiary of ESA funds received by Hungary on two occasions. The first major support was used to implement the revised version of the Genius Integrated Talent Support Programme (2010-13), and the so-called Talent Bridges Programme (2013-14). The two programmes targeted the fundamental restructuring of Hungarian talent support and are of priority importance within the National Talent Programme as a means to ensure the cooperation of the public and the private sector. The main components of the network were the introduction of the concept of the Talent Points, the theoretical grounding of the relevant professional standards, and awareness-raising through the internet.

The youngest NGO in talent support is the European Talent Centre (EUTC) based in Budapest, formed in mid2012, funded mainly by the Hungarian National Talent Programme. It is dedicated to goals aligned with the guidelines of the NTP, so it aims to make the Hungarian talent programmes visible in foreign languages, to prepare best practices for adaptation in the European Union, to organise EU Talent Days, and to initiate EU co-operation and international experience exchange. Co-operation between EUTC and ECHA, the European Council for High Ability is exceptionally important in this work.

Generally, it can be stated that these organisations provide a stable and permanent institutional and 
professional framework for the implementation of many talent support programmes in Hungary, so the system on the structural and political level has been developed and functions well. Our primary challenge today is to make a real and practical use of this system, and to provide an appropriate education, treatment and support for the gifted and their supporters on the individual and on the classroom-level.

\section{Challenges in identification}

Talent identification is a challenging issue throughout the world. As a complex and multi-faceted issue, identification always carries the possibility of overlooking vital points. The following areas are critical fields of the identification process in all countries, which have to be taken into consideration when planning a national or local strategy.

\section{To define "talent"}

For an appropriate process of talent identification, we need a concrete definition of what we are looking for, what we aim to identify. However, what is "talent"? What do we mean by "giftedness"? Turning the pages of, for example, a more than 400-page book entitled Conceptions of Giftedness (Sternberg \& Davidson, 2005), it becomes absolutely clear that giftedness is such a complex issue, and talent is the result of the interaction of so many factors, that it is already impossible to define, what it is. For example, let us examine the well-known and relatively simple three-ring model of giftedness by Renzulli (1998), according to whom, "research on creative-productive people has consistently shown that although no single criterion can be used to determine giftedness, persons who have achieved recognition because of their unique accomplishments and creative contributions possess a relatively well-defined set of three interlocking clusters of traits. These clusters consist of above average, though not necessarily superior, ability (1), task commitment (2), and creativity (3)" (para. 41). These elements should be examined individually. Measuring abilities and intelligence has a long tradition in psychology, and some methods are well-established, such as Progressive Matrices, Wechsler's Intelligence Scale, the StanfordBinet Intelligence Scale, or some later developments, such as IST or Sternberg Triarchic Abilities Test (STAT). However, less conservative intelligence models, such as Gardner's Multiple Intelligences theory (1983) or the idea of Successful Intelligence (Sternberg, 1997), question former theories and measurement methods. In the light of new theories, we cannot be completely sure about the nature and the elements of intelligence (Sternberg \& Kaufman, 2011), thus the measurement of intelligence is basically determined by our understanding and interpretation of intelligence itself. Moreover, what about creativity? Measuring it seems to be at least as complicated as measuring intelligence (Péter-Szarka, 2013). There are some well-known tools, such as Torrance's Test of
Creative Thinking or Urban's Test for Creative Thinking - Drawing Production (TCT-DP; Urban, 2005), but recent research showed that environmental factors notably influence the creative process (Péter-Szarka, 2012), which means that creativity is more dynamic and inconstant than creativity tests suggest. So, measurement, again, becomes difficult. Task commitment and motivation are changing very fast: from day to day, from subject to subject, and from exercise to exercise. Measuring it is almost impossible. Some questionnaires aim to measure the structure of motivation, such as the AchievementGoal Questionnaire (AGQ; Elliot, Murayama \& Pekrun, 2011) or the Academic Motivation Scale (AMS; Vallerand et al. 1992), but they cannot give us a reliable prediction of the extent of students' efforts into given tasks.

This short review illustrates that even a relatively understandable talent definition, such as Renzulli's model, sets up several problems for identification. If we want to establish our identification process on Gagne's (2008) or Ziegler's (2005) more complex and dynamic models of giftedness, the challenge of matching definitions and identification processes is much greater.

\section{Talent as a potential}

In recent talent models (Gagne, 2008; Ziegler, 2005), talent appears as a result of a long developmental process. It theoretically implies the fact that talent identification in childhood is always the identification of talent potential, not the fully developed talent. Moreover, the "potential" has a long way towards full development. Resulting from the complex and interactive nature of intrapersonal and environmental factors, the "chance" factor and many other things, we can hardly make any concrete prediction of later productivity. Identification processes (except for retrospective studies) can identify only the "potential", but not the "developed talent". In the light of these theories, it seems necessary to establish a developmental perspective in the explanation of excellence.

\section{Environmental factors}

Novel theories and models on giftedness emphasize the interactive process between the individual and its environment. Theories including or focusing on the environmental determinants of giftedness do not question the significance of individual and personal characteristics, but focus on the catalyst-function of the surroundings. They emphasize the fact that individual qualities cannot evolve without a supportive environment, and environmental factors may mobilize and even develop personal skills.

For example, Mönks's model (1992) expanded the Three-ring Conception of Giftedness developed by Renzulli (1986) by including the influences exerted by peers, parents and teachers. A further theory to include environmental factors into the determinants of talent development is the Differentiated Model of Giftedness and Talent model developed by Gagné (2008), in which the environment acts as a catalyst of talents. 
Ziegler (2005) also emphasizes that giftedness, conceptualized as the property of an individual, can no longer function as an independent concept. Instead, giftedness and talent must be something more than merely personal attributes and that at minimum includes the environment in which an individual is acting, and it must be integrated into the construct.

The interactive nature of the individual-environment relationship makes the assessment of the environment even more complicated. As Gagne (2008, p. 4) says, "the bulk of environmental stimuli have to pass through the sieve of an individual's needs, interests, or personality traits. Talentees continually pick and choose which stimuli will receive their attention."

In the light of these theories, identification processes should also include environmental factors. Csíkszentmihályi (2009) gives a conceptual framework, the systems theory of creativity and a list of questions that help us to make decisions whether a given environment is talent- and creativity-friendly or not. He says that creativity with a capital " $\mathrm{C}$ " — the kind that changes the way we see or understand the world - never happens in the mind of a person exclusively, but can be observed only in the interrelations of a system made up of three main elements: the domain, the field and the person. In addition, the level of creativity of a nation is not the sum of the individual creativities of its population, but it rather depends on how conducive to creativity its various societal institutions are. To measure the elements of the system, to identify "talent-friendly environment", we need to answer the following questions: How easy is it for a person to retrieve the information stored in the culture? How easy is it for people to be exposed to different ways of thinking and acting? How many institutions are present in a culture for learning and practicing a particular domain? How easy is it for a child to pursue his or her interest, and learn to be an excellent biochemist, poet, philosopher-or whateverand still preserve his or her personal curiosity and vision? How much support does the society provide to new ideas? To what extent are adults involved in stimulating excellence and novelty in children-preferably outside the classroom in realistic situations? Moreover, how many opportunities are there in businesses, universities, civic organisations to express and implement novel ideas? To what extent are curiosity, exploration, originality, intense involvement with one's interests encouraged at the level of various levels of the life cycle?

Answering these question and measuring outstanding ability beyond the person-centered assessments is a great advantage of creating a talent-friendly environment and society.

\section{Importance of perseverance, motivation, the role of actions}

Based on Ericsson's decisive work on the role of deliberate practice (Ericsson, 1998; Ericsson, Krampe \& Tesch-Römer, 1993), recent research emphasizes that talent cannot be defined by static, personal attributes, and the "characteristic of the developmental process of excellence is the execution of an extremely large number of actions in a specific domain" (Ziegler, 2004. p. 7). Gyarmathy (2014) also underlines that active participation and engagement in an activity in a given field is a fundamental condition for unfolding one's talent. According to some estimations (Ericsson, 1998), duration of actions, needed for unfolding of one's talent, usually add up to a total of about 10,000 hours of deliberate practice.

Research from the direction of positive psychology also suggests something similar. In their pioneering article "Self-discipline Outdoes IQ in Predicting Academic Performance of Adolescents", Duckworth and Seligman (2005) formulate that self-discipline predicts academic performance more robustly than IQ does. In their research, self-discipline also predicted which students would improve their grades over the course of the school year, whereas IQ did not. According to these results, the virtue of "consciousness" and "self-discipline" seems to be of greater importance than intellectual excellence.

In 1985, Csikszentmihalyi wrote, "the unifying similarity among geniuses and innovators is not cognitive or affective but motivational. What is common among them is the unwillingness or inability to strive for goals everyone else accepts - their refusal to live by a presented life theme" (p. 114).

These ideas suggest that time investment, effort, motivation, perseverance and other non-cognitive, energetic factors that mobilize skills and abilities have key roles in the process of talent development. As these factors are dynamic and directly influenced by environmental factors, they are not easy to identify.

\section{Individual variety}

As a result of various personal attributes interacting with several environmental factors, there is a rich variety of talent developmental processes. Similar gifts may lead to different competencies. As Gagne (2008, p. 6) says, "gifts represent generic abilities that can be molded into somewhat divergent skills, depending on the field of activity adopted by a talantee". One type of gift or natural ability may be the basis of several, later developed competencies. For example, manual dexterity, as one of many natural physical abilities, can be moulded into the particular skills of a pianist, a dentist, a typist, or a videogame player. "These contributions can vary a lot in intensity and continuity from one talentee's story to another. No two developmental paths look alike. Consequently, talent development is a very complex process, a process where the four causal components modify their interactions over the course of a talentee's developmental path" (Gagne, 2008, p.6). In addition, different areas of talent have different developmental trajectories, and some fields are much better than others at identifying where students are in these developmental trajectories and providing them with a roadmap for achieving success. It means that there is not one single way to develop talent, and that if identification is based only on standardized test scores and group comparisons, it does not give space for the rich variety of individuals' talents. 


\section{Practices of identification in Hungary}

In Hungary, the professional discussion about the appropriate talent identification practices continues. In October 2013, there was a national conference and a panel discussion about important theoretical and professional questions, including the definition of giftedness and the new challenges, problems and perspectives of identification.

How is "talent" defined in Hungary? The Public Education Act of Hungary from 2011 defines gifted or talented students as "students requiring special treatment, who are highly creative and possess above-average general or special skills, and strong motivation and commitment may be generated in them towards the task" (CXC, 2011, $4 \S)$. This act defines care for the particularly gifted or talented students as an obligation of the secondary school, integrated into the everyday educational processes. The definition is based on the Renzulli-model but lacks some of the important elements I referred to above: talent as a potential, individual variety, individual-environmental interactions and the necessity of effort. Éva Gyarmathy (Fuszek, et al., 2014) suggests an alternative definition: "Talent can carry out activities in an outstanding level through challenging tasks and opportunities, as a result of which $\mathrm{s} /$ he is capable of outstanding achievement." (p. 102). It suggests a more dynamic view of talent, thus provides an alternative way of defining and understanding talent.

How do we identify talented students? As I described above, we have a national-level network of institutions, but do not have a national-level identification strategy. There are regional solutions, so Talent Points decide what to measure and how to do so. The chosen identification method fits the purpose of the special talent support program into which the students are selected. If there is a gifted program, for example for mathematics or for drawing, the identification process cannot be the same: it has to be adapted to the content of the program. Identification is practically based on a chosen theory of giftedness that gives comparatively clear guidance of the examined areas. In Hungary, Renzulli's Three-ring model and Gardner's Multiple Intelligence model are the most popular theories for general identification practices. However, the Genius and Talent Bridges programs support gifted students, who were identified by their achievements, e.g. contest-results or outstanding accomplishments.

Despite the rich variety of tools and methods for identification, there are some main principles that are taken into account when planning an identification process:

- complexity: to use measures not only from the intellectual, but also other relevant domains

- specificity: identification methods should be specifically related to the examined area

- flexibility: students are examined from time to time to get the chance for getting into and out of the talent pool
- multiple perspective: application of different methods, such as psychological testing, teachers' and peers' opinion, competition results, school achievement.

What methods are used? The most widely used methods are the following:

- Examining school achievement on the basis of grades and teachers' opinion.

- Competition results.

- Students' portfolios, results and productions.

- Collecting opinion from teachers, peers, family, themselves, which is usually carried out in written forms, interviews or focus groups.

- Psychological testing to measure cognitive abilities, motivation, creativity, and other characteristics such as self-esteem, learning strategy, anxiety, or any other relevant traits.

- Observation of mental, emotional, behavioural and social characteristics at school, at normal classes or with special tasks. It is very effective, although timecostly and rare.

What tools are generally used for psychological testing? Practically, it depends on the given situation and the special program. However, there are some widely used tests and questionnaires for different areas. For cognitive skills, Hungarian versions of Raven Progressive Matrices and CAT (Cognitive Abilities Test) are widely used, as they can be completed in groups. In some special cases, Wechsler's Intelligence Scale and the Stanford-Binet Scale are used, but cognitive profile tests are also becoming increasingly popular. For motivation, we generally use a Hungarian questionnaire by Kozéki and Entwistle (1986), as well as a questionnaire measuring mastery motivation. Some new motivational questionnaires have been translated and adapted in recent years, and they should be tested in gifted education. In the field of motivation, success-oriented attitude and attitudes toward learning are often examined. For the measurement of creativity, the well-known Torrance Tests are the most general, but two Hungarian questionnaires are also becoming increasingly popular: the Creative Leisure Activities and the Assessment of the Creative Personality (Tóth \& Király, 2006).

For other areas, the most popular questionnaires are STAI (State-trait Anxiety Inventory by Spielberger; Spielberger et al., 1983), Tennessee's Self-concept Scale (Fitts, 1965), Rosenberg's Self-esteem Scale (1965), and some Hungarian questionnaires for learning characteristics and learning attitudes. For teacher nomination, the Renzulli-Hartman Scale (Renzulli et al., 2002) is widely used, however, only the first version from 1975 with four subscales has been translated into Hungarian.

In Debrecen, the second biggest town of Hungary, with about 200,000 inhabitants, there is a regional initiation for screening all the $4^{\text {th }}$ grade students of the public schools, and to provide a gifted program for about $15 \%$ of them from the next year. The program is planned for generally 
intellectually gifted children, and aims to give the chance for them to try out and get acquainted with different science and art areas. In this program, psychological testing includes the measurement of attention, memory (verbal, visual) analogical and logical thinking skills, and two additional subject tests (Hungarian language, mathematics) are carried out. Teachers' opinions are also collected about the students' learning habits, individual learning methods, self-esteem, underachievement and special skills. It is a regional program, but its methodology has been used in other, local projects (Pappné \& Pakurár, 2011).

What are the strong points of Hungarian identification practices? They include autonomy of institutions, plurality, flexibility, commonly accepted principles, the highly stable network of Talent Points, opportunities for cooperation and sharing ideas, and the relative stability of political and governmental support.

What are the weak points? Relatively old tools are used, often without or with old norms. Standard identification practices do not always work with low SES children, which may call for inequality in chances. Excluding children from gifted programs with the reasons for low or insufficient test scores is ethically questionable. Mostly the tools and methods represent a static, mechanistic and rigid view of talent, without the space for individual variety and environmental factors. Measurement always implies that we reduce talent into some measurable elements, which is the basis for professional mistakes. There is a relatively small number of tools for special skills. Labelling of gifted children may be problematic.

\section{Conclusions, steps forward}

On the basis of the strong and weak points of the Hungarian system and the challenges of identification, we must draw some conclusions and see how we can develop our identification practices. In the coming years, we have to pay more attention to include the following aspects into the identification process:

- The use of cognitive profile tests: In order to avoid the dangers of linear and narrow-focused categorization by IQ, it seems to be more appropriate to measure cognitive skills by profile tests. Profile tests give a thorough picture of one's cognitive skills in many areas. It enables to see the strong and weak points of one's skills in its complexity. It may serve as a basis for individual developmental plans.

- Investigation of interest-based characteristics: Differences in interests play a critical role in many gifted students' options and choices, and we need to understand more deeply what sparks and enhances those interests. If students have been identified based on general ability and there is no clear sense of a given child's talent domain and interests, it is probable that the child will not develop as much as he or she would have were interests taken into account (Subotnik, Olszewski-Kubilius \& Worrell, 2011). The topic of interests - how they are nurtured, developed, maintained, or lost - is one that should elicit further research in understanding giftedness.

- The use of observation: Observation of one's behaviour in action, in a challenging activity or in a difficult task within one's natural environment seems to be more reliable than artificial or "laboratory" results. Identification with observation is even more important in the early years, because any type of measurement is much less reliable in early childhood, because of the developmental differences and the lack of "test-readiness". In this way, the identification of gifted children takes place by simple observation of the child's behaviour by an educational or a psychological professional, or a parent. Identification by characteristics or behavioural traits is generally accurate and is less intrusive or conspicuous than other methods. It also readily allows types of giftedness to be detected, and is often valuably used with young children. Nonetheless, subjective elements are certainly involved particularly in comparisons with other children of the same age.

- The use of dynamic assessment methods: Assessing children from culturally and linguistically diverse backgrounds can be a complex task. One alternative to standardized testing methods is dynamic assessment, which is a method of conducting an assessment that seeks to identify the skills that an individual child possesses as well as their learning potential. The dynamic assessment procedure emphasizes the learning process and accounts for the amount and nature of examiner investment. It is highly interactive and process-oriented, describes modifiability.

- The use of teacher nomination with guidelines: This method allows teachers to nominate students who display characteristics that are not easily determined by tests. Teachers need some help in recognizing talent and recognizing the stereotypical beliefs they hold about gifted and talented students, so usually a teacher nomination form and rating scales are used for this procedure. Scales can be used to provide a composite profile of the nominated students.

- Emphasizing development, the need for effort: As research results show, perseverance, effort and practice are necessary for development. Teachers and psychologists should encourage students to put enough energy into activities and send a hidden message of "flexibility" and the changing nature of skills. Creating space for a "growth mindset" is essential (Dweck, 2006).

Keeping in mind the above principles, some promising efforts to broaden our test-battery for talent identification have been made. The Cognitive Profile Test (Smythe, 2002) has been adapted from English into Hungarian to map different cognitive skills of younger and older children, 
and is becoming more and more popular. Map of Interests (Gyarmathy \& Herskovits, 1999), based on the Gardner multiple intelligence theory, is often used to map interestfields of students. Curios Chest is a special, diagnostic device for the activity-centred talent identification and the mapping of the interests of children aged 4-8 years. We plan to adapt the Nebraska Starry Night Observation Protocol (Griffin \& McKenzie, 1993) in the near future, which involves identifying the wide range of observable characteristics that may indicate special types of ability in very young children. We also plan to translate and adapt the latest version of the Renzulli Rating Scale for rating the behavioral characteristics of superior students, which is a tool that is widely used in many countries. At the moment, we are putting a great deal of effort into research about mindset and perseverance, and also into the adaptation process of these questionnaires.

In summary, we have a good and stable institutional framework and basis for talent development, but as our environment is continually changing, we have to adapt to new challenges and enrich our professional expertise in the light of new research results. The focus from identification toward investigation, exploring individual needs and characteristics to provide the most appropriate pathway for development seems to be a more effective way of talent support then mere selection in the 21 st century.

\section{References}

LXXIX. Act of Public Education (1993). Retrieved from http://www.okm.gov.hu/letolt/kozokt/kozokt_tv_ 070823.pdf

CXC. Act of National Public Education (2011). Retrieved from http://njt.hu/cgi_bin/njt_doc. cgi?docid=139880.226439

Csikszentmihalyi. M. (1985). Emergent motivation and the evolution of the self. In D. Kleiber \& M.H. Maehr (Eds.), Motivation in Adulthood (pp. 93-119). Greenwich, CT, USA: JAI Press.

Csíkszentmihályi, M. (2009). A systems perspective on creativity and its implications for measurement. In E. Villalba (Ed.), Can creativity be measured? International conference volume (pp. 407-414). Brussels, Belgium: European Commission, Directorate-General for Education and Culture, Centre for Research on Lifelong Learning. Retrieved from http://bookshop.europa. eu/en/measuring-creativity-pbLBNA24033/

Duckworth, A. L., \& Seligman, M. E. P. (2005). Selfdiscipline outdoes IQ in predicting academic performance of adolescents. Psychological Science, 16(12), 939-944.

Dweck, C. (2006). Mindset: The new psychology of success. New York, NY, USA: Ballantine Books.

Elliot, A. J., Murayama, K., \& Pekrun, R. (2011). A 3X2 Achievement Goal Model. Journal of Educational Psychology, 103(3), 632-648.
Ericsson, K. A. (1998). The scientific study of expert levels of performance: General implications for optimal learning and creativity. High Ability Studies, 9, 75-100.

Ericsson, K. A., Krampe, R. T., \& Tesch-Romer, C. (1993). The role of deliberate practice in the acquisition of expert performance. Psychological Review, 100(3), 363-406.

Fitts, W. H. (1965). Manual for the Tennesse Self Concept Scale. Nashville, TN, USA: Counselor Recordings and Tests.

Fuszek, C. (2014). An overview of the current status of talent care and talent support in Hungary. CEPS Journal, 4(3), 55-71.

Fuszek, C., Arató, F., Balogh, L., Bodnár, G., Gyarmathy, É., Péter-Szarka, S., \& Vass, V. (2014). Ez is tehetséggondozás! [It is also talent support!]. Iskolakultúra, 4, 100-120.

Gagne, F. (2008). Building gifts into talents: Overview of the DMGT. Retreived from http:/www.sfu.ca/ $\sim$ kanevsky/428/Gagne.pdf

Gardner, H. (1983). Frames of mind: The theory of multiple intelligences. New York, NY, USA: Basic Books.

Griffin, N. S., McKenzie, J. (1993). Nebraska Starry Night: A behavior-based observation protocol, version 8.893. Lincoln, NE, USA: University of Nebraska-Lincoln.

Gyarmathy, É. (2014). A nem szunnyadó erő: A tehetség fogalmának átgondolása [Power that is not sleeping: Rethinking the concept of giftedness]. Neveléstudomány, 2, 67-81. Retreived from http://nevelestudomany.elte.hu/downloads/2014/ nevelestudomany_2014_2_67-81.pdf

Gyarmathy, É., \& Herskovits, M. (1999). Képességek vizsgálata az érdeklődés térképének segítségével [Investigation of abilities with the help of mapping interests]. Pszichológia, 19(4), 437-458.

Kozéki, B. \& Entwistle, N. J. (1986): Tanulási motivációk és orientációk vizsgálata magyar és skót iskoláskorúak körében [Examination of learning motivation and orientation among Hungarian and Scottish students]. Pszichológia, 6(2), 271-292.

Mönks, F. J. (1992). Development of gifted children: The issue of identification and programming. In F. J. Mönks, W. A. M. Peters (Eds.), Talent for the future (pp. 191-202). Assen/Maastricht, Netherlands: Van Gorcum.

Pappné Gyulai, K., \& Pakurár, M. (2011). A debreceni példa. Tehetségazonositás és tehetséggondozás a város közoktatási intézményeiben [The example of Debrecen. Talent identification and talent development in the public schools of the town]. Budapest, Hungary: Magyar Tehetségsegítő Szervezetek Szövetsége.

Péter-Szarka, S. (2012). Creative climate as a means to promote creativity in the classroom. Electronic Journal of Research in Educational Psychology, 10(3), 1011-1034. 
Péter-Szarka, S. (2013). Guidelines for the assessment of creativity. ECHA News, 27(2), 8-9.

Renzulli, J. S. (1986). The three-ring conception of giftedness: A developmental model for creative productivity. In R. J. Sternberg \& J. E. Davidson (Eds.), Conceptions of giftedness (pp. 53-92). New York, NY, USA: Cambridge University Press.

Renzulli, J. (1998). Three-ring conception of giftedness. In S. M. Baum, S. M., Reis, \& L. R. Maxfield (Eds.), Nurturing the gifts and talents of primary grade students. Mansfield Center, CT, USA: Creative Learning Press. Retrieved from http://www.gifted. uconn.edu/sem/semart13.html

Renzulli, J. S., Smith, L. H., White, A. J., Callahan, C. M., Hartman, R. K., \& Westberg, K. L. (2002). Scales for rating the behavioral characteristics of superior students - revised edition. Mansfield Center, CT: Creative Learning Press.

Rosenberg, M. (1965). Society and the adolescent selfimage. Princeton, NJ, USA: Princeton University Press.

Smythe, I (2002). Cognitive factors underlying reading and spelling difficulties: A cross linguistic study (Thesis submitted for the degree of Doctor of Philosophy). Department of Psychology, School of Human Sciences, University of Surrey, Guildford, UK.

Spielberger, C. D., Gorsuch, R. L., Lushene, R., Vagg, P. R., \& Jacobs, G. A. (1983). Manual for the State-Trait Anxiety Inventory. Palo Alto, CA, USA: Consulting Psychologists Press.

Sternberg, R. J. (1997). Successful intelligence. New York, NY, USA: Plume.

Sternberg, R., Davidson, J. (Eds.) (2005). Conceptions of Giftedness. New York, NY, USA: Cambridge University Press.

Sternberg, R. J., \& Kaufman, S. B. (Eds.) (2011). The Cambridge handbook of intelligence. New York, NY, USA: Cambridge University Press.

Subotnik, R. F., Olszewski-Kubilius, P., \& Worrell, F. C. (2011). Rethinking giftedness and gifted education: A proposed direction forward based on psychological science. Psychological Science in the Public Interest, 12(1), 3-54.

Tóth L., \& Király Z. (2006). Új módszer a kreativitás megállapítására: A Tóth-féle Kreativitást Becslő Skála [A new method for the assessment of creativity: The Tóth Creativity Assessment Scale]. Magyar Pedagógia, 106(4), 287-311.

Urban, K. K. (2005). Assessing creativity: The Test for Creative Thinking - Drawing Production (TCT-DP). International Education Journal, 6(2), 272-280.

Vallerand, R., Pelletier, L., Blais, M., Briere, N., Senecal, C., \& Vallieres, E. (1992). The Academic Motivation Scale: A measure of intrinsic, extrinsic, and amotivation in education. Educational and Psychological Measurement, 52, 1003-1017.
Ziegler, A. (2004). The Actiotope Model of Giftedness. Retrieved from http://www.psycho.ewf.uni-erlangen. de/mitarbeiter/ziegler/publikationen/Publikation02a. pdf

Ziegler, A. (2005). The Actiotope Model of Giftedness. In R.J. Sternberg \& J.E. Davidson (Eds.), Conceptions of Giftedness (pp. 411-436). New York, NY, USA: Cambridge University Press. 